\title{
The Concept of Nahy Munkar and Islam; Study on Habib Rizieq's Legal Thought
}

\author{
$1^{\text {st }}$ Siti Chuzaemah ${ }^{1}, 2^{\text {nd }}$ JM. Muslimin ${ }^{1}, 3^{\text {rd }}$ Hamka Hasan $^{2}$ \\ \{khuzaimahmuhammad2212@gmail.com¹,jm.muslimin@uinjkt.ac.id ${ }^{1}$, hamkahasan@uinjkt.ac.id² $\}$
}

UIN Syarif Hidayatullah, Islamic Studies Department, Jakarta, Indonesia ${ }^{1}$, UIN Syarif Hidayatullah, Dirasat Islamiyah Department, Jakarta, Indonesia ${ }^{2}$

\begin{abstract}
This article discusses the concept of Nahy Munkar FPI which includes criteria, guidelines, and steps in his preaching that are identical with violence and this is what led him to the label of "radical" in his Islamic movement. Behind the actions carried out by FPI, due to several factors one of them is one of them due to differences in understanding in a text. This research uses librabry research, with a historical socio approaches. To analyze and express the thoughts of Habib Rizieq about Nahy Munkar and Islam. This study focuses on books by Habib Rizieq entitled Dialogue of the FPI Amar Makruf Nahi Munkar and Destroying Liberalism and Establishing Islamic Sharia.
\end{abstract}

Keywords: Radical Movement, Radicalism, Nahy Munkar, FPI

\section{Introduction}

In the reformation era, radical Islamic movements in Indonesian in began to emerge and develop, cause politics were opened increasingly and governance were weak.[1] Nahy Munkar's actions were implemented often clash with state officials.[2] To response this movement, the government took a firm stand by imprisoning FPI's leaders and tried to dissolve the movement because it was considered disturbing the community.[3] FPI (Islamic Defenders Front) which was established by Habib Rizieq after the new order on August 17 1998[4] was one of the movements so that the radical movement is called this movement. Criticism, condemnation, accusations as provocateurs and instigators are always referred to this organization as well.[4]

The following are the actions of the evil people who have been realized by FPI, including (1) expelling the Ketapang thugs, under the command of the FPI Ketapang incident in 1999, becoming the first large-scale thug cleansing icon in the capital, (2) overcoming Banyuwangi ninja, (3) participated in the Ambon war in 1999 and the Poso war (in 1998-2001), (4) in 2006, FPI encircled Playboy magazine, and demanded that it withdraw all of its circulating magazines.[5]

Besides getting accusations from the legal apparatus, agree or disagree with FPI's existence, not only in the public but also among academics or scholars. Those can be seen by the articles discussed about FPI, including Abdul Hakim Wahid reviewing articles on The FPI Understanding's Model of the Qur'an and Hadith, he disagrees with the members because their acts of violence have exceeded the limits so that it shifted from the main goal moreover caused a negative image of violence acts laid on Islam.[1] 
The statement above is a line with Machfud Syaefudin that he disagrees about acts of violence implemented by FPI because law enforcement, norms, and social order are the responsibility of the state (government) not FPI.[6] They are different with Asfa Widiyanto who agrees with FPI's violent attitude and considers that the attitude of violence and tenderness in preaching Amar Ma'ruf Nahy Munkar is still considered by Habib Rizieq, and it is based on the Qur'an and Hadith.[7]

As has been explained Habib Rizieq is one of the main figures for the actions carried out by FPI, so the researcher will try to explore and uncover about concept of Nahy Munkar and Islam's Habib Rizieq objectively through his opuses, including The FPI's Dialogue about Amar Ma'ruf Nahy Munkar and Destroy Liberalism Uphold Islamic Sharia where his thoughts on the Nahy Munkar are still being debated by the public. For this reason, this article attempts to describe and analyze the concept of Nahy Munkar Habib Rizieq thoroughly, and what lies behind his thinking.

\section{The Thinking of Nahy Munkar and Islam's Meaning}

Thinking according to the KBBI comes from words that mean intellect, memory, imagination, experts. Thinking is using common sense to consider and decide something. Whereas the thinker is a clever person, the genius whose thinking results can be used by someone, such as philosophers. So based on language thinking is a process, a way or an act of thinking; problems that require thought (way, process) and solving.[8]

According to Samsul Nizar, thinking is an attempt to solve problems, as well as the process of efforts of physical and mental work to see facts wisely.[9] So indirectly, researchers know that thinking is empowerment to solve problems and make decisions that will produce something new.

\subsection{The Meaning of Nahy Munkar}

Before knowing the meaning of Nahy Munkar and more fully the meaning of the Amar Ma'ruf Nahy Munkar, in fact, the phrase is derived from the Arabic language in Indonesian, originally “ الأمر بالمعروف والنهي عن المنكر” (al-Amr Bil Ma'ruf wan Nahyu 'An al-Munkar).

According to Habib Rizieq Al-Amr bi al-Ma'ruf it means demanding to perform all virtues or good deeds according to Islamic law and bring the culprit closer to Allah. While al-Nahy and al-Munkar means to prevent something being denied according to Islamic law and keep the perpetrator away from Allah.[1]

Another case, Abdul al-Karim Zidan, a professor of Islamic Law at University Shana'a Yaman said that the purpose of Amar Ma'ruf Nahy Munkar according to fuqaha' is to enjoin goodness when goodness is ignored, and prevent munkar when it is clearly done. In line with Ali Musthofa Ya'qub, one of Member of the Central MUI Fatwa Commission said that Amar Ma'ruf Nahy Munkar is demanding all actions which according to common sense or religion are known as good, and prevent everything that according to common sense or religion is bad.[10]

From the statement above, the derivation of the meaning of Amar Mar'uf Nahy Munkar has the same but different emphasis. For example, in the context of Habib Rizieq, only the Islamic Shari'ah is the benchmark for determining goodness and evil. While Ali Musthofa 
Ya'qub not only emphasized the Shari'a but common sense also took part in measuring the benchmarks of goodness and evil, and this opinion was in line with Abdul Karim Zidan.

\subsection{The Meaning of Islâm}

Related to the meaning of Islam, in Ibn Manzûr's dictionary, Lisân al-'Arab, it is explained that the term al-islâm comes from the word Salima-Yaslamu-Salâman-Salâmah which means safety, freedom, and salvation from something. Al-Silm, al-Salm, and al-Islâm are the opposite of al-Harb or war. Ibn al-A'rabî said that al-Salâmah means al-'afiyah or health.[11] Therefore, Allah brought al-Islâm and called it the term Salâm, which at the end with al-Islâm was then ordered to spread Salâm. So Ibn 'Arafah interpreted Islam as a manifestation of no hostility, war, let alone violence.[12]

According to al-Farrâ and al-Zajjâj, Islam is derived from the basic word sîn-lâm-mîm

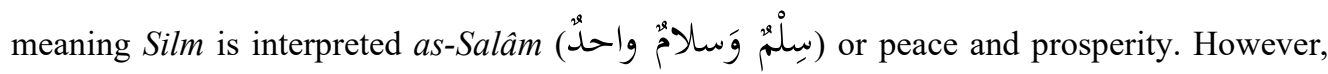
according to Abû Haitsam ( السلام والتحية معناهما واحد، ومعناهما السالامة من جميع الآفات) gives specificity that al-salâm is welfare and peace that is more physical. The next meaning is al-Taslîm which is based on al-Salâm or one of the names of Allah. because it is free from shame and lack and acts as the Most Observing.[13]

From the various meanings above, Muhammad bin Yazid said that among Arabs the term al-salâm is identical with four things, namely al-salâm which is understood as the plural form of salâmah. Second; al-salâm which is based on one of Allah's names. Third; al-salâm means tree and al-salâm which is meant by prayer for others to avoid danger both in their religion and themselves. It is in this fourth aspect that al-salâm is a sincerity.[13]

Furthermore, the term al-islâm and al-istislâm mean (1) inqiyâd and al-khud $\hat{u}^{\prime}$ (surrender and submission). Al-Islam in the context of Shari'a is to show obedience and shari'a, and to be consistent with what comes from Muhammad Saw. Therefore, some claim that what is called Islam is faith by word of mouth and heart. Abû Bakr Muhammad Ibn Basysyar responded that the so-called Muslims are those who surrender everything to Allah, and sincerity of worship because of Allah (سلّم الشيى لفلان أي خلصوا). Other meanings of al-islâm is entering into the door of salvation (أسلم فلان فلانا إذا ألقاه في الهلكة ولم يحمو من عدوّه

From the various meanings of al-Islam above, it can be known that al-islâm as a manifestation of humility and willingness to oblige themselves to be obedient and obedient to what is brought by the Prophet Muhammad Saw, even al-islâm is interpreted as purification or oral purification, and faith that is in the heart. So that the meaning of this kind is very closely related to what was said by Abû Bakr Muhammad bin Basyar that Islam is surrender and all problems to God, and the sincerity and sincerity of worship only because of God.[14]

Apart from some definitions of Islam according to the term, here the researcher only describing the definition of Islam according to Abdul Mujib because Abdul Mujib can represent several definitions that exist, namely the celestial religion handed down by Allah to His servants through the Apostles,[15] Habib Rizieq said that Islam is a religion of peace, but that does not mean resignation to evil and tyranny. Islam is a religion of gentleness, but that does not mean silence against cruelty and brutality. Therefore, Habib Rizieq defines and connects it with Amar Makruf Nahy Munkar and immorality which is rampant in Indonesia.[4] 
From the derivation of the meaning of Islam above, there are fundamental differences from Habib Rizieq and traditional scholars who will deliver it also to behave differently in implementing Shariah, especially in upholding the Amar Ma'rûf Nahy Munkar. Traditional scholars interpret Islam as a manifestation of the peace and prosperity of relations between humans and God, and humans and fellow human beings. While Habib Rizieq defines Islam as a manifestation of the tenderness and violence nature of the existence of cruelty and ignorance.

\subsection{A Glimpse of The Habib Rizieq's Life History}

Muhammad Rizieq bin Husain Syihab,[16] or popular with the greeting Habib Rizieq, while his small nickname is not Muhammad or Rizieq, but Ayib.[5] He was born on August 241965 M. / 27 Rabiul Sani 1385 H in Jakarta.[17] He is the son of Habib Husein bin Syihab[17] and Syarifah Sidah al-Attas.[5] The house is located at Jln. Petamburan III No. 83, Tanah Abang, Central Jakarta.[18] He was not born in a boarding school environment. Nevertheless, since an early age he has wanted and learned the very large science of religion. When he was four years old, he diligently recited Koran (al-Qur'an) in mosques.[17]

At the age of 22, Habib Rizieq's mother asked him to marry. His mother also showed the girl for him to observe, the girl named Syarifah Fadhlun. Saturday morning at around 09.00 WIB on September 111987 in the Bogor area West Java, Habib Rizieq married Syarifah Fadhlun.[5] The marriage of Habib Rizieq with Syarifah Fadhlun was blessed with 7 daughters, namely Rufaidah, Humaira, Zulfa, Najwa, Mumtaz, Fairuz, and finally Zahra.[17] While the baby's eldest daughter died first due to miscarriage.[5] After marriage, Habib Rizieq along with his wife and children live in a modest house located on Jalan Petamburan III.[18]

Regarding Habib Rizieq's profession, he is active in organizations, especially in the FPI movement and teaches both in the formal and informal fields. In 1993 after his return from study in Saudi Arabia, he also actively taught at the "Majelis Ta'lim" and Aliyah Jami'at Kheir[16] located in KH. Mas Mansyur Tanah Abang Central Jakarta. In 1994, he became Wakepsek (Deputy Principal). From 1995 to 1996, he held the position of Principal of the Madrasah Aliyah Jam'iat Kheir Madrasah. Although he no longer serves as the Principal there, he actively teaches as a teacher in the fields of jurisprudence or Usul Fiqh and inheritance (Faraid).[5]

In addition, Habib Rizieq has also been a Sharia Board of the BPRS At-Taqwa Tangerang, leader or coach of a number of Ta'lim assemblies throughout Jabodetabek and founder of an international standard agro-cultural boarding school, Board of Trustees of the Islamic Community Forum (FUI), Board of Trustees of the National Imamat Committee (DIN), Board of Trustees of the Aqsa Liberation Committee (KPA), Board of Trustees of the Indonesian Red Hilal (HILMI), Advisory Board Rabithah al-Alawiyah and Board of Trustees of the Anti-Corruption Fighters 45. Habib Rizieq is also the Grand Mufti of the Sulu Malaysia Sultanate on March 19 2009, with a DPMSS title (DPMSS). Datuk Paduka Maulana Syar'ia Sulu). He was also offered to be a lecturer at the University in Malaysia where he completed his Magister"s studies.[17]

From some of the Habib Rizieq careers mentioned, there are probably 3 careers that made the center of the propagation of preaching Amar Ma'ruf Nahy Munkar and his thoughts namely when he became the leader of the FPI, the Imam of the Sultanate of Sulu and the founder of the Agricultural boarding school because a leader is the holder of control of a community so that he will be more it's easy to offer his ideology. 
The level of education Habib Rizieq had started to learn in mosques since the age of 4 years.[17] Formally, he studied at SDN 1 Pertamburan. His location is still on street Petamburan IV Petamburan Village Tanah Abang and he graduated with a very satisfying value in 1975 when he was not even 10 years old. Therefore, he is referred to as a very outstanding student achievement. Then he continued his study with a scholarship at SMPN 40 Pejompongan, Bendungan Hilir Tanah Abang.[5] Because Habib Rizieq was young and the school was 3 kilometers away, his mother finally canceled his scholarship and moved to Bethel Petamburan Christian Middle School, which was closer to his home.[18]

At Bethel Middle School, Habib Rizieq was known as a student who disputed teacher doctrine. His popularity is increasingly becoming when his rebuttal often breaks the arguments of the interlocutors of the same age as the pastors.[5] Even he can refuse the missionary action to him without having to have an ongoing dispute. Even so, until now he still maintains a good relationship with the pastor and the Christian community around his home environment. Tolerance still he held, as long as mutual respect there is no reason to hate each other.[18]

In 1979 when Habib Rizieq is the age of 14 years, he graduated from Bethel Christian Middle School. Then Habib Rizieq continued his education at SMAN 4 on Jalan Batu No. 3, Gambir Sub-District, Gambir Sub-District, Central Jakarta. However. Not yet a year he attended SMAN 4, his mother was interested in moving house. Coinciding when the grade was up, he moved to grade 2 at the Islamic Village High School on Jalan Imam Bonjol, Kelapa Dua, Karawaci, Tangerang.[16]

After graduating from Islamic Village High School, Habib Rizieq was interested in deepening Arabic knowledge. In 1984, he registered at LPBA (Arabic Language Education Institute), an institution owned by the Islamic University of Imam Muhammad bin Saud, KSA (Kingdom of Saudi Arabia), located in Salemba Raya East Jakarta. Because of his intelligence, he got a scholarship to continue his studies at the Tarbiyah Faculty, Fiqh and Usul Department, King Saud University. In 1984, with the blessing of his mother, he left for Riyadh Saudi Arabia. At King Saud University, Habib Rizieq studies various branches of science in the Dirâsah Islâmiyyah's faculty or Islamic religious studies.[16] In 1990, he graduated with a degree in Fiqh and Usul from King Saud University with cumlaude.[5]

After winning the cumlaude degree at King Saud University in 2004, Habib Rizieq again received a Magister's scholarship at the University of Inter-Malaysia. But after only a year of his studies, the scholarship system changed. The impact of the system change, Habib Rizieq was forced to stop continuing its studies at the university because it was burdening its economy. In 2006, he won another scholarship at the Islamic Faculty of Islamic University of Malaya (USIM) located in Kuala Lumpur Malaysia, and graduated in 2010 with a predicate cumlaude. Then, Habib Rizieq resumed his studies to the doctoral field at the same University, with the same title.[5] [16]

Habib Rizieq also underwent non-formal education by following Taklim assemblies including Habib Council Abdullah Al-Faqih Al-Attas, Habib Assembly Muhsin bin Ahmad Al-Attas, Majelis KH. Abdullah Syafii Al-Batawi, Majelis KH. Aminullah Al-Batawi, Sayyid Muhammad bin Alawi Al-Maliki Council (Mecca), Habib Muhammad Muhammad al-Haddar (Madinah) Council and many more.[18]

From some of the teachers mentioned above, Habib Rizieq along with Ustadz Hassan Daniel and Ustadz Otman Shihab had studied at al-Husaini under the guidance of the late Habib Muhsin bin Ahmad Alatas. This teacher is a strict fiqh expert. He will say black is black, white is white, halal is halal and haram is haram. It was he who gave the most encouragement and color to Habib Rizieq's thoughts because he was the one who introduced 
Habib Rizieq about what Islam was. This is the most memorable and that is what is applied by Habib Rizieq in family and society.[19]

From the biography of Habib Rizieq's educational history above, there is something unique from Habib Rizieq, namely at the young age of 10 years, when he attended the Bethel Christian Middle School the doctrine that was expressed by the teacher he disputed. In fact, he was able to break the argument of priests whose age was far from him. His uniqueness shows and proves that he is a man of above-average because of his intelligence and firmness since he was a child which is able to distinguish between right and wrong.

Habib Rizieq has been known by all the public with his intelligence, and because of the intelligence he has, so he wrote several works in which contained his thoughts about Islam in Indonesia and the preaching Amar Makruf Nahy Munkar. The works of Habib Rizieq that are known include: (1) Dialogue of the FPI Amar Makruf Nahy Munkar, this book contains about answering questions and against the anti-immoral national movement in Indonesia. This book is the result of his work which was completed in a prison cell in 2003. (2) National Insight Towards the Homeland of the Sharia Republic of Indonesia, this book contains a complete scientific and factual review of various national issues. (3) Destroy Liberalism Enforce Islamic Sharia, this book contains a sharp criticism of Liberalism who wants to attack Islam with their free ideology.

Therefore, from the explanation above, there are approximately 3 very easy means to influence and transform an ideology, namely through education, power, and environmental conditions.

\section{The Concept of Nahy Munkar and Violence}

\subsection{Nahy Munkar}

Islam came to contain the commands and prohibitions that were denied in the concept of Amar Ma'ruf Nahi Munkar. To uphold Amar Ma'rûf Nahy Munkar as a whole, Habib Rizieq offers FPI preaching steps, namely: (1) Enriching Amar Makruf, by holding a remembrance assembly and science assembly in the whole country in order to treat those who are victims of immorality. (2) Upholding Nahy Munkar, by destroying immoral nests which are the center of the distribution of immorality. (3) Enhancing Amar Makruf Nahy Munkar, by eradicating evil and dangerous immoral mosquitoes (perpetrators), by starting from the softest to the firmest and harshest when forced.[4]

No one can deny that a gentle and wise attitude is praiseworthy, even it must be put forward in a variety of situations and conditions, especially in applying for good knowledge.[4] But for Habib Rizieq violence is a reflection of two attitudes. First, a reflection of the firmness of attitude and rigidity of principles. Second, a reflection of the rudeness of attitude and cruelty of the heart.

Violence as a firm reflection of the attitude and rigidity of principle is praiseworthy violence, and does not conflict with the Shari'a and this is a follow-up of process Amar Makruf Nahy Munkar with unresolved tenderness. In addition, because in the letter at-Taubah verse 73 Allah ordered the Messenger of Allah to be hard on the infidels and munafiq. Allah said:

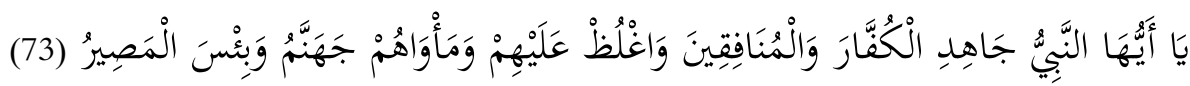


"O Prophet! Fight against unbelievers and hypocrites, and be cruel to them. Their place is hell. And that is the worst of their places." (QS. Al-Taubah: 73)

A violence is a gross reflection of attitude and hatred is despicable, and is forbidden by the Shari'ah or backward with the prudent tenderness taught by Islam, and because in the letter of Ali Imran verse 159 explained that Allah Swt to preach with wisdom, smart, smart, gentle and should not be rude or harsh. Allah SWT said:

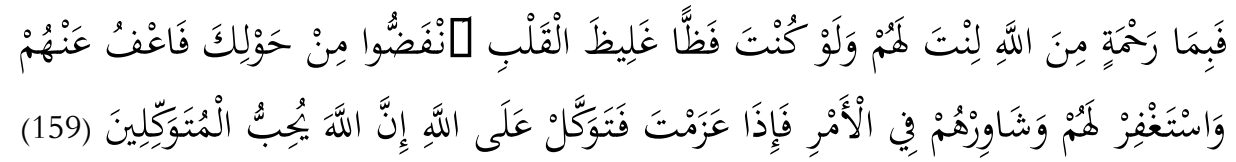

"By the grace of Allah, you (Muhammad) have been gentle towards them. If you are hard-hearted and harsh-hearted, they will certainly stay away from you. Therefore, forgive them and beg for their forgiveness, and consult with them in the matter. Then when you have decided, fear Allah. Indeed, Allah loves those who trust." (QS. Âli 'Imrân: 159)

From the arguments above, Habib Rizieq concludes that Amar Makruf Nahi Munkar is an obligation to all Muslims and it cannot strictly enforced except with a strong and stern attitude, so it is obligatory for the strict and complete obligation of Amar Makruf Nahy Munkar. So the rules of jurisprudence apply:

$$
\text { ما ل يتم الواجب إل به فهو واجب }
$$

"What is imperfect is an obligation except with it, so it becomes obligatory."[20] Assertiveness and firmness in such conditions is not despicable violence, even praiseworthy for being the usual struggle for the perfect Amar Makruf Nahy Munkar that is being fought for. Therefore this commendable violence is justified in the Koran and Sunnah, and has been an inseparable part of the struggle of Islam since the beginning of time until now. [48]

As for QS. Al-Taubah: 73 which was used by Habib Rizieq as an argument to commit violence against infidels and hypocrites (munafiq) is contrary to the statements of al-Tabarī and al-Zamakhsyarī. It means that both of them oppose the obligation to fight or commit violence against hypocrites. The suitable way to jihad against hypocrites is by word of mouth (lisan) or hujjah not by war or violence. Therefore, violence is not appropriate to be carried out by Muslims in jihad, especially in upholding Nahi Munkar against other fellow Muslims.

As for the explanation of some of the FPI missionary steps as mentioned above, the first point does not get any opposition among the public even the method used has become a culture in Indonesia. This is evidenced by the existence of a number of pesantren which serve as a means for the assembly of knowledge and dzikir. However, at the last two points this is identical with violence. The violence carried out by FPI as an Indonesian citizen is not in accordance with the statement of Azyumardi Azra as a Professor of Indonesian Historians that Indonesia has a cultural distinction that is relatively different from other countries, namely a peaceful, friendly and tolerant character. Therefore it is not surprising that the violent attitude carried out by FPI has become problematic in the public because it is against the majority.

Defending religion and defending religion is an effort to maintain the continuity of the experience of religious teachings safely and calmly by keeping away all forms of violence that endanger the purity of religion. This understanding includes efforts to oppose the suppression of religion, fight against justice and oppose evil. This is the substance of the battle of the Prophet. And this is precisely what is the substance of the destruction of immoral sites. So both of them have a substantial equation.[4]

It is said that one day there were hypocrites among the Khazraj tribe known as Abu Amir Ar-Rahib who built the mosque for intentions of harm, but they gave reasons while swearing 
that the mosque's construction was intended for policies such as protection of the weak and ease of worship in winter. After the construction of the mosque, they invited Rasulullah Saw to pray with them at the mosque. Because at that time, he Saw and his companions were at the height of their preparations for departure to Tabuk, the Holy Prophet answered them:

$$
\text { إنا على سفر، ولكن إذا رجعنا إن شاء الله }
$$

"We are in preparation for traveling, but if we return, God willing."[21]

When Rasulullah SAW returned from Tabuk, near the city of Medina, Gabriel came to bring the revelation of Allah Almighty:

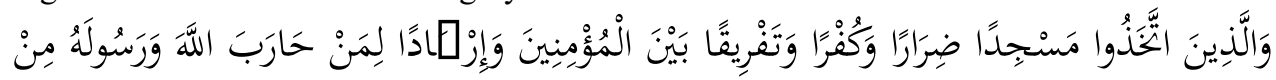

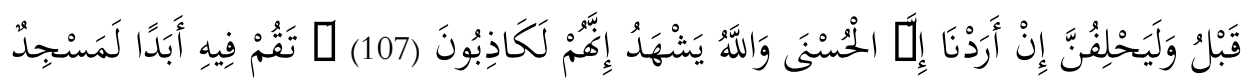

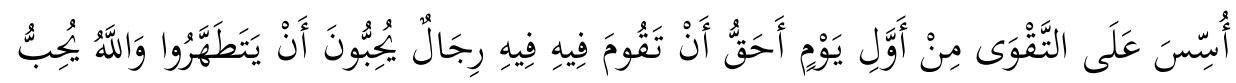

$$
\begin{aligned}
& \text { الْمُطِّهِرِينَ (108) }
\end{aligned}
$$

"And (among the hypocrites) there are those who build mosques to cause harm (to the believers) and to their disbelief, and to divide the believers and wait for the coming of the people." who have fought against God and His Messenger for a long time. They swore, "We will do nothing but good." And Allah bears witness that they are liars. Do not mislead in the mosque forever. Indeed, the mosque was erected based on piety (Quba Mosque), since the first day you ought to pray in. Some wish to be cleansed, and Allah loves those who are clean." (QS. Al-Taubah: 107-108)

It was through this revelation that the Messenger of Allah Saw came to know that the mosque was intended for harm, disbelief, fragmentation, and as a place to spy on the movements of the people, as well as for the return home of Abu Amir to bring enemy reinforcements. Therefore, the Messenger of Allah. sent the people to the Dirar Mosque to demolish it before he arrived in Medina. Either say to Malik bin al-Dakhsyam Ma'in bin Ma'di to be sent:

$$
\text { انطلقا إلى هذا المسجد الظالم أهله، فاهدماه واحرقاه }
$$

"Go to the mosque of the abusive inhabitants, and destroy and burn the mosque."[21]

And the story of the "idolatry" of the Passover Fathu Makkah is part of the final destruction done by Abraham. Although this is the way the Prophets are doing it, Allah Almighty has not condemned it but called them radical or called their actions anarchist.[4]

In the case of the burning and destruction of the Al-Dhirar mosque and the destruction of the temple, Habib Rizieq used the rules of Fiqih:

$$
\text { العبرة بعموم اللفظ ل بخصوص السبب }
$$

"Taking the argument/law with the generality of the word, not with the specificity of the cause".[4]

So when Habib Rizieq uses this argument, then the consequence is the generality of the proposition includes any event, anywhere and anytime, which has the same substance. This general quality will remain valid as long as no other proposition specializes.[4]

From this incident, Habib Rizieq was able to take two very important lessons relating to the problem of destroying immoral places, namely: (1) Impossible places as places where 
Munkar deserve to be destroyed and burned, whatever the name given to the place of Munkar, both names that are beautiful connotes policy, especially a name that blatantly connotes immorality. (2) If a place called "mosque" alone can be destroyed and burned when it is proven to be a den of denial. What about the "Headquarters of Stupid", "apostasy center", "shamanism practice", "brothel location" and various other places that have proven to be places of evil transactions ??.[4]

After examining the information above regarding the substance of the Prophet's war as described, it is clear that the background to the war is religious oppression and fighting against evil and opposing wrongdoing. While the violence carried out by FPI is not because of the explicit oppression of religion but only the occurrence of munkar. Therefore, this violence is not appropriate to be done in public.

In connection with the denial that was determined Habib Rizieq above turned out to be different from Yusuf Qardawi's statement, that to change and enforce the denial could be done with heart, and this could be done by severing relations with the places of negations. It is clear that in upholding the Munkar the disobedience, because by destroying the same way the Munkar is replaced by a new Munkar. Things like this are not prescribed in religion.

According to Habib Rizieq, the destruction or burning of immoral places involves one of the technicalities in the enlistment of Amar Makruf Nahy Munkar. The determination of the law is very dependent on the level of usefulness and harm caused, without being separated from the influence of the existing situation and conditions. And related to the law of destruction/burning of immoral places, then the description of possible laws that arise, namely: (1) Obligatory, if the evil can not be eliminated except by being destroyed/burned, while its harm is almost completely absent. (2) Mandub if the benefits of destruction / burning far outweigh its harm, and the harm is easily avoided. (3) It is permissible if the benefits of destruction/burning are far greater than its harm, and the harm is difficult to avoid. (4) Makruh, if the benefits and it's Mudharat balanced. (5) Haram, if delivering to the greater Mudharat.[4]

In this context, if it is correlated with the sweeping it does, the ruling on destruction falls under the category of Haram. Because the destruction of the immoral places he committed led to the massive arrests of FPI activists in the 2000s, even acts of terror such as the shooting of his characters also often occur. In this case indirectly leads to greater harm so that the destruction of immoral places is not justified, moreover the action was carried out without seizing the government. This causes the mobilization of libel and can even destroy the country.

Habib Rizieq said that in determining the law, an in-depth study must be carried out with extra careful caution and must be carried out by experts. And apart from the five laws, then by considering fiqh preaching the destruction and burning of immoral places must be avoided as much as possible. Habib Rizieq also strives to find other alternatives even though it requires more sacrifice of time, energy and mind. Because indeed the considerations of "impressions" include considerations that have been made by the Prophet Muhammad Saw in the struggle for propaganda.[4]

There is no doubt that FPI is one of the main tools for Habib Rizieq to uphold the Amar Makruf Nahy Munkar, and in FPI has 4 methods in carrying out each of its activities:

First, FPI must prioritize tenderness, while decisive action is only the final solution. Second, FPI is only concerned about the type of "disobedience" that has been agreed upon, not that which is still being disputed. Third, FPI only reduces immorality which is carried out openly and openly. Fourth, FPI divides two regions: the Amar Makruf action area and the Nahy Munkar action area. 
The area of Amar Makruf is the area of immorality supported by the local community or at least the community is not disturbed by disobedience, such as livelihood issues. In this region, FPI must not take violent action against immorality, because it will only create clashes with people who basically do not yet have good religious awareness. To avoid horizontal conflict between communities, the FPI is obliged to conduct Amar Makruf by spreading preaching in such areas to awaken the people from the dangers of immorality.

Whereas the Nahy Munkar area is an immoral, immoral domain of immorality and rejected by the local community or at least the community has been surrendered and disturbed by existing immoral activities. In this region, FPI is obliged to optimally encourage and assist local communities to take firm action against all disobedience, because the level of religious awareness of the local community is not relatively good. The role of FPI here as a servant of the people in conducting Nahy Munkar.[4]

Regarding FPI's way of realizing Amar Makruf Nahy Munkar such as upholding the Nahy Munkar by destroying the central place of Munkar, the researcher considers that FPI is inconsistent with its statement because immoral places in Indonesia are still very numerous, and FPI has not burned down immoral places.

\subsection{Islamic Law: Country Without Prison}

Until now, Indonesia has not upheld the Islamic Shari'a so the applicable laws do not refer to Islamic teachings. FPI is dealing with two legal provisions: first, religious law and second, state law.

Religious law is absolute, must be obeyed as a whole and there is no way to work around this. So Amar Makruf Nahy Munkar who fought for by FPI must obey and obey the rules that apply in Islamic law. Medium state law is not absolute if it is by following religious norms, we are obliged to obey it, otherwise, if it clashes with religion we must reject it. In rejecting this, strategy and strategy are needed.[4]

Here is one of the secrets contained in the word of God:

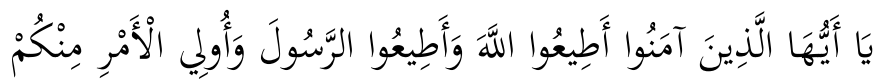

"O you who believe, obey Allah and obey His Messenger, and be obedient to you." (QS. Al-Nisâ ': 59)

In that verse, according to Habib Rizieq, "obey" Allah SWT and the Messenger of Allah. As for Ulil Amri, whether it means scholar or umara, it is only explained to the former. This is a scholarly study that obedience to Allah SWT and the Messenger of Allah (may peace be upon him) is absolute; If it is lawful to obey, then it is illegal to obey.[4] The Messenger of Allah (may peace be upon him) said:

$$
\text { 口 طاعة لمخلوق في معصية الخالق، إنما الطاعة فن المعروف }
$$

"There is no obedience to the creatures in immorality to the Khaliq (the creator). Indeed obedience is only in virtue."[22]

Therefore, the pattern of FPI fighters in the struggle for Amar Makruf Nahy Munkar is subject to Islamic sharia rules. Regarding state law, FPI will submit as long as it does not conflict with religious teachings. As for a set of rules and regulations that contradict the Islamic Shari'a, the FPI in its struggle will try to work around this so that it avoids bridging against state law while continuing to strive to change any misleading legal provisions towards Islam. This is a liability.[23] 
Just as civil law in Indonesia does not deserve to be called a positive law, because it results in many negative things, such as social problems, the inheritance of revenge, waste of state money, no deterrent effect, and does not guarantee the sense of security of the community. Besides, civil law does not have religious benefits such as forgiveness and blessings, on the contrary, it only adds sin and eliminates blessing, thus making the country more dilapidated and destroyed. While Islamic law benefits the religion, and solve the problem to the root of the problem. Thus, according to the standard capability of a type of law and resolving legal issues, the civil law does not deserve to be called a positive law, but Islamic law is the most appropriate so that Islamic law should be formalized as the law of the Republic of Indonesia. Therefore, by Islamic law, we should be able to build a country without prison.[17]

As explained above that Wawu Athaf in the word Ulil Amr Minkum surat al-Nisa: 59 is only Athaf before. This is contrary to the rules of Nahwu that the benefit of the letters Athaf Wawu is Mutlaq al-Jam'. So it is not suitable if people are only required to obey Allah and the Apostle but also are required to obey the government. As for civil law, it is still needed, even though it cannot stop Munkar comprehensively but civil law can minimize neglect and this is a form of security provided by civil law and does not need to be changed into Islamic law. As for Islamic law, it is also not suitable for the State of Indonesia, hence with the distinction of Indonesia "tolerant" embracing the diversity of cultures and religions that exist within the State's foundation namely Pancasila and the 1945 Law.

\section{Conclusion}

From some of Habib Rizieq's thoughts about Nahi Munkar and Islam above, researcher still disagree with his anarchist attitude because they didn't get permission from the government. But if they have a position as a government then the anarchist attitude is justified. The results of Habib Rizieq's thoughts about Nahi Munkar and Islam are motivated by differences in how to read and differences in understanding the meaning of a text and the terms "Nahi Munkar" and "Islam". Wallahu A'lam

Acknowledgements. This research supported by The Graduate School of Islamic Studies UIN Syarif Hidayatullah.

\section{References}

[1] A. H. Wahid, "Model Pemahaman Front Pembela Islam (FPI) Terhadap Al-Qur'an dan Hadis," Refleksi, vol. 17, no.1, 2018.

[2] A. Rosadi, Hitam Putih Front Pembela Islam, Jakarta: Nun Publiser, 2008.

[3] I. Hasan, Radikalisme Agama Jabodetabek dan Jawa Barat, Jakarta: Publikasi Setara Institut, 2010 .

[4] M. R. b. H. Syihab, Dialog FPI Amar Ma'ruf Nahi Munkar; Menjawab Berbagai Tuduhan Terhadap Gerakan Nasional Anti Maksiat di Indonesia, Jakarta: Pustaka Ibnu Sidah, 2013.

[5] I. U. Junior, Habib Rizieq Shihab Singa Allah Dari Negeri Timur, Jakarta: Pujangga, 2017.

[6] M. Syaefudin, "Reinterpretasi Gerakan Dakwah Front Pembela Islam (FPI)," Jurnal Ilmu 
Dakwah, vol. 34, no. 2, 2014.

[7] A. Widiyanto, "Violence in Cotemporary Indonesian Islamist Scholarship: Habib Rizieq Syihab and Enjoining Good and Forbidding Evil," Nomos Verlagsgesellschaft, 2017.

[8] Kamus Besar Bahasa Indonesia, Jakarta: Balai Pustaka, 2005.

[9] S. Nizar, Pengantar Dasar-Dasar Pemikiran Islam, Jakarta: Gaya Media Pratama, 2001.

[10] A. M. Ya'qub, Panduan Amar Makruf Nahi Munkar, Cet. 1, Jakarta: Pustaka Firdaus, 2012.

[11] A.-R. Al-Ashfahāni, Mu'jam Mufradāt Alfāz al-Qur'ān, Bairut: Dar al-Kutub al-Ilmiah, 2004.

[12] J. R. Hinnels, Dictonary of Religiouns, Inggris: Pengiun Books, 1995.

[13] J. a.-D. M. i. M. i. M. a. F. Misri, Lisan Al-Arab, Bairut: Dar al-Sadir, 2010.

[14] A. Q. I. Ibn Abbad, al-Muhith fi al-Lughah, Alam al-Maktab, 1994.

[15] A. Mujib, Kepribadian Dalam Psikologi Islam, Jakarta: Raja Grafindo, 2006.

[16] F. Muhammadi, Sisi Lain Habib Rizieq, Jakarta: Pujangga Tunggal, 2017.

[17] M. R. Syihab, Wawasan Menuju NKRI Bersyari'at, Jakarta: Islam Press, 2012.

[18] F. Quraisyiah, "Pemikiran Dakwah Habib Muhammad Rizieq Husein Syihab, MA." UIN Jakarta, 2014.

[19] https://www.nahimunkar.org/siapa-guru-yang-mewarnai-pemikiran-habib-rizieq/posted on 12 November 2013.

[20] M. b. a. H. b. M. b. K. Al-Farra', Al-Iddah fi Ushūl al-Fiqh, Riyadh, 1990.

[21] I. a.-Q. a.-D. Ibn Kathir, Tafsir al-Qur'an al-Azhim, Maktabah al-Shafa, 2004.

[22] M. b. S. b. J. b. A. b. H. Al-Mishri, Musnad al-Syihab, Bairut: Mu'assasat al-Risalah, 1986.

[23] M. R. Syihab, Hancurkan Liberalisme Tegakkan Syari'at Islam, Jakarta: Islam Press, 2013. 